\title{
Casca de Arroz Como Adsorvente Para Extração Mspd de Aflatoxinas B1 e M1
}

\author{
Priscila Scaglioni (I), Eliana Badiale Furlong (I) \\ (I) FURG - Universidade Federal do Rio Grande (Avenida Itália km 8 - Programa de Pós- \\ Graduação em Eng e Ciência de Alimentos)
}

\section{Resumo}

A capacidade adsortiva da casca de arroz já foi comprovada em diversos estudos, sugerindo que pode ser usada como adsorvente na técnica MSPD, podendo substituir adsorventes convencionais e gerar menos resíduos químicos. Neste trabalho verificou-se a capacidade da casca de arroz de adsorver as aflatoxinas $\mathrm{B}_{1}$ e $\mathrm{M}_{1}$ presentes em leite, utilizando-se como referência a extração descrita na AOAC. A casca de arroz foi tratada previamente com lavagens com metanol e hexano e posterior secagem. A casca tratada e moída (32 mesh) foi acondicionada em seringas, ocupando um volume de $1 \mathrm{~cm}^{3}$, e estas foram acopladas a um sistema de vácuo manifold, por onde posteriormente amostras de leite fortificadas com as aflatoxinas $\mathrm{B}_{1}$ e $\mathrm{M}_{1}$ foram eluídas. Após foi realizada uma lavagem com uma mistura de metanol e clorofórmio. O método da AOAC consistia em utilizar metanol e celite, limpeza com cloreto de sódio 4\% e sulfato de sódio anidro, partição com hexano e extração final com clorofórmio. Os extratos obtidos foram quantificados por cromatografia líquida de alta eficiência. A corrida foi realizada a $35^{\circ} \mathrm{C}$, com vazão de $1,0 \mathrm{~mL} \mathrm{~min}{ }^{-1}$, detector de fluorescência nos $\lambda_{\text {excitação }}=360 \mathrm{~nm}$ e $\lambda_{\text {emissão }}=450 \mathrm{~nm}$ e coluna Kromasil C18 5 $\mu$ 250x4,6mm. Comparando os métodos, o emprego da casca de arroz promoveu uma redução significativa no gasto de solventes, pois no método oficial para cada $5 \mathrm{~mL}$ de leite são utilizados $65 \mathrm{~mL}$ de cloreto de sódio, $20 \mathrm{~mL}$ de metanol, $30 \mathrm{~mL}$ de hexano e $20 \mathrm{~mL}$ de clorofórmio, além de celite e sulfato de sódio anidro, enquanto que empregando a casca de arroz, para $10 \mathrm{~mL}$ de leite foram gastos apenas 4,8 $\mathrm{mL}$ de metanol e 1,2 $\mathrm{mL}$ de clorofórmio. Os cromatogramas mostraram 
nítida diferença entre os extratos obtidos, sendo que usando a partição da AOAC ocorreram diversos interferentes (15 picos em corrida de 15 min), além disso, após a eluição dos picos a linha de base não foi alcançada, dificultando a integração da área do pico no tempo de retenção da aflatoxina $\mathrm{M}_{1}$, que elui primeiro (aproximadamente $2 / 3$ da corrida). $\mathrm{O}$ extrato de leite fortificado que passou pela casca de arroz apresentou menor interferência, mostrando picos gaussianos e linha de base normal. A eluição completa das micotoxinas do adsorvente foi demonstrada pela obtenção de cromatogramas sem interferentes e recuperação de 82 e 94\%, respectivamente para as aflatoxinas $\mathrm{B}_{1}$ e $\mathrm{M}_{1}$.

Palavras-Chave: adsorvente, aflatoxina, casca de arroz Agência de Fomento: 